\title{
In Vitro Propagation of Catha edulis
}

\author{
Hamid M. Elhag' \\ College of Pharmacy, King Saud University, P. O. Box 2457 Riyadh \\ 11451, Saudi Arabia
}

Additional index words. tissue culture, khat, micropropagation

Khat [Catha edulis (Vahl) Forssk. ex Endl., Celastraceae] is a perennial shrub or small tree that grows wild and is cultivated in certain regions of the Middle East and eastern Africa. The leaves are commonly chewed while fresh to alleviate hunger and to produce stimulating effects, but habitual use is often associated with social and medical problems (Shadan and. Shellard, 1962). Because khat may have other pharmacological properties (Al-Meshal et al., 1986; Nordal, 1980), there is a need to provide reliable and uniform plant material for further studies on secondary plant products. This report describes in vitro propagation of khat.

In a preliminary study, eight shoot tips obtained from the new growth of a greenhouse-rooted cutting were used as explants. Shoot tips $(5-7 \mathrm{~mm})$ were surface-sterilized by soaking in a $20 \%(\mathrm{v} / \mathrm{v}) \mathrm{NaOCl}$ solution with a drop of Tween 80 for 5 min and rinsed three times in sterile distilled water. Explants were cultured initially on a medium contain-

Received for publication 14 Dec. 1989. This research was supported by a grant from the Research Center of the College of Pharmacy, King Saud Univ. The cost of publishing this paper was defrayed in part by the payment of page charges. Under postal regulations, this paper therefore must be hereby marked advertisement solely to indicate this fact.

'Research Scientist.

ing the inorganic salts of Murashige and Skoog (1962), B5 vitamins (Gamborg et al., 1968), and the following (in mg.liter ${ }^{-1}$ ): glycine, 2.0; sucrose, 30,000; meso-inositol, 100; $\mathrm{N}$ (phenylmethyl)-1H-purin-6-amine(BA),3.0; $1 \mathrm{H}$-indole-3-acetic acid (IAA), 0.3; and Bacto agar, 8000 at pH $5.7 \pm 0.1$. After autoclaving, $25 \mathrm{ml}$ of medium were dispensed in $25 \times 150$-mm culture tubes. Cultures 'were maintained at $23 \mathrm{C}$ with an 18 -h photoperiod of $22.5 \mu \mathrm{mol} \cdot \mathrm{s}^{-1} \cdot \mathrm{m}^{-2}$ provided by cool-white fluorescent lamps.

After 8 weeks on the above medium, the explants proliferated clusters of shoot buds that averaged $15 \times 15 \mathrm{~mm} /$ cluster. Upon transfer to media with various concentrations of BA and IAA, the bud clusters either developed into shoots of variable lengths or consistently proliferated more buds on medium with BA at $3.0 \mathrm{mg} \cdot \mathrm{liter}^{-1}$ and IAA at $0.3 \mathrm{mg} \cdot$ liter $^{-1}$.

To determine the optimum concentrations of BA and IAA for multiple-shoot formation and growth from shoot-tip explants, rather than bud clusters, the experiment was repeated with terminal shoot tips ( $5 \mathrm{~mm}$ long) isolated from shoots formed in vitro in the previous experiment. Shoot tips were recultured on the same basal medium used previously with $\mathrm{BA}$ at $0,0.3,1.0$, or 3.0 $\mathrm{mg} \cdot$ liter $^{-1}$ in factorial combination with IAA at $0,0.3$, or $3.0 \mathrm{mg} \cdot$ liter $^{-1}$, with 10 replications per treatment in a completely random

Table 1. Effect of BA and IAA on multiple-shoot formation and rooting in recultured shoot-tip explants of Catha edulis ( 10 cultures per treatment) after 8 weeks.

\begin{tabular}{cccccr}
\hline \hline $\begin{array}{c}\text { BA } \\
\left(\mathrm{mg} \cdot \text { liter }^{-1}\right)\end{array}$ & $\begin{array}{c}\text { IAA } \\
\left(\mathrm{mg} \cdot \text { liter }^{-1}\right)\end{array}$ & $\begin{array}{c}\text { Cultures with } \\
\text { multiple shoots } \\
(\%)\end{array}$ & $\begin{array}{c}\text { No. shoots } \\
\geq 5 \mathrm{~mm} / \\
\text { culturey } \\
( \pm \mathrm{SE})\end{array}$ & $\begin{array}{c}\text { Mean shoot } \\
\text { length/ } \\
\text { culture } \\
(\mathrm{mm} \pm \mathrm{SE})\end{array}$ & $\begin{array}{c}\text { Cultures } \\
\text { with roots } \\
(\%)\end{array}$ \\
\hline 0 & 0 & 10 & $2.0 \pm 0.0$ & $15.0 \pm 1.0$ & 0 \\
& 0.3 & 10 & $2.0 \pm 0.0$ & $20.0 \pm 2.0$ & 60 \\
0.3 & 3.0 & 0 & $1.0 \pm 0.0$ & $35.0 \pm 5.0$ & 100 \\
& 0 & 80 & 0 & $2.0 \pm 0.0$ & 0 \\
1.0 & 0.3 & 100 & $10.0 \pm 3.4$ & $6.4 \pm 1.8$ & 0 \\
& 3.0 & 100 & $13.0 \pm 3.5$ & $7.0 \pm 1.6$ & 0 \\
& 0 & 60 & $4.3 \pm 1.3$ & $6.0 \pm 1.0$ & 0 \\
3.0 & 0.3 & 100 & $8.4 \pm 2.1$ & $6.2 \pm 1.2$ & 0 \\
& 3.0 & 20 & 0 & $2.0 \pm 0.0$ & 0 \\
& 0 & 20 & $3.5 \pm 0.5$ & $5.0 \pm 0.0$ & 0 \\
& 0.3 & 60 & 0 & $2.0 \pm 0.0$ & 0 \\
\hline
\end{tabular}

${ }^{2}$ Values refer. to the-percentage of explants that produced multiple shoots.

ZZero values do not indicate absence of multiple shoots, since only shoots $\geq 5 \mathrm{~mm}$ were recorded. design.

In the absence of BA, IAA at both concentrations tested promoted shoot elongation and rooting, with very little or no formation of multiple shoots (Table 1). When BA was included in the medium, the explants either transformed into clusters of multiple buds $(\leq 2 \mathrm{~mm})$, with the percentage decreasing as BA level was increased, or formed multiple shoots $(\geq 5 \mathrm{~mm})$ in the presence of MA. The greatest number of shoots $(\geq 5 \mathrm{~mm})$ was obtained with BA at $0.3 \mathrm{mg} \cdot$ liter $^{-1}$ plus IAA at 0.3 or $3.0 \mathrm{mg} \cdot$ liter $^{-1}$, which elicited $100 \%$ multiple shoot formation (Table 1). The effect of BA and IAA, as well as the BA $\times$ MA interaction on the number of shoots $\approx 5$ $\mathrm{mm}$, was highly significant (Table 2 ). Replacement of BA with either N-(3-methyl-2butenyl)-1EI-purin-6-amine (2iP) or $\mathrm{N}-(2$ furanylmethyl)-1H-purin-6-aqine (kinetin) at 0.3 or $3.0 \mathrm{mg} \cdot$ liter $^{-1}$ in the presence of IAA at $0.3 \mathrm{mg} \cdot$ liter $^{-1}$ did not enhance multiple-shoot formation (data not presented).

Root development was promoted by IAA and inhibited by BA (Table 1). At least $30 \%$ of rooted plantlets were acclimatized and established in soil in the greenhouse. A large portion of the plantlets was used in pharmacological studies before transfer to soil. (Elhag et al., 1990). Our results demonstrate successful micropropagation of khat.

\section{Literature Cited}

Al-Meshal, I.A., M. Nasir, and F.S. El-Feraly. 1986. (-)-N-Formylnorephedrine from Catha edulis. Photochemistry 25:2241.

Elhag, H., M. El-Domiaty, F. El-Feraly, LA, AlMeshal, and M.M. El-Olemy. 1990. Studies on (-)-cathione formation in tissue cultures of Catha edulis (Khat). Abstr. VIIth Intl. Congr. Plant Tissue and Cell Cult., Amsterdam, 24-29 June 1990:316

Gamborg, O.L., A.R. Miller, and K. Ojima. 1968. Nutrient requirements of suspension cultures of soybean root cells. Expt. Cell Res. 50: 151-158.

Murashige, T. and F. Skoog. 1962. A revised medium for rapid growth and bioassays with tobacco tissue cultures. Physiol. Plant. 15:473497.

Nordal, A. 1980. Khat: Pharmacognistical aspects. Bul. Narcotics 32(3):51-66.

Shadan, P. and E.J. Shellard. 1962. An anatomical study of Ethiopian khat (leaf of Catha edulis. Forssk.). J. Pharmacy \& Pharmacology 14:110-118

Table 2. Analysis of variance for number of shoots $\geq 5 \mathrm{~mm}$ formed in vitro per shoot-tip explant.

\begin{tabular}{|c|c|c|c|c|}
\hline $\begin{array}{l}\text { Source of } \\
\text { variation }\end{array}$ & $\mathrm{df}$ & $\begin{array}{l}\text { Sum } \\
\text { squares }\end{array}$ & $\begin{array}{l}\text { of } \text { Mear } \\
\text { square }\end{array}$ & $n \quad \begin{array}{c}\mathrm{F} \\
\text { value }\end{array}$ \\
\hline $\mathrm{BA}$ & 3 & 1034.5 & 344.8 & $66.3 * * *$ \\
\hline IAA & 2 & 245.2 & 122.6 & $38.6 * * *$ \\
\hline BA X IAA & 6 & 1036.8 & 172.8 & $54.4 * * *$ \\
\hline Error & 108 & 343.0 & 3.2 & --- \\
\hline
\end{tabular}

${ }^{* * *}$ Significance at $P=0.001$. 